$4^{\text {th }}$ International Meeting on Calcitonin Gene-Related Peptide (CGRP)

TheScientificWorld (2001) 1(S1), 13

ISSN 1532-2246; DOI 10.1100/tsw.2001.443

\title{
THE EFFECT OF CALCITONIN GENE-RELATED PEPTIDE (CGRP) ON THE CYTOSOLIC CALCIUM CONCENTRATION AND FORCE IN RAT INTRAMURAL CORONARY ARTERIES
}

\author{
M. Sheykhzade and N.C.B. Nyborg \\ Department of Pharmacology, The Royal Danish School of Pharmacy, Universitetsparken 2, 2100 \\ Copenhagen $\varnothing$, Denmark
}

The aim of this study was to investigate the mechanism of CGRP-induced relaxation in intramural rat coronary arteries. By using FURA-2 technique, cytosolic $\mathrm{Ca}^{2+}$-concentration $\left(\left[\mathrm{Ca}^{2+}\right]_{\mathrm{i}}\right)$ was measured during contraction of the vascular smooth muscle with receptor-dependent agonist (tromboxane $\mathrm{A}_{2}$ analogue U46619) and with high concentration of extracellular potassium. At a steady state of contraction, the increase in $\left[\mathrm{Ca}^{2+}\right]_{\mathrm{i}}$ induced by $300 \mathrm{nM}$ U46619 (100 " $\times 14 \mathrm{nM}, n=$ 7) was similar to that induced by $36 \mathrm{mM} \mathrm{K}^{+}(98 " \times 9 \mathrm{nM}, n=7)$. However, the active tension induced by $300 \mathrm{nM}$ U46619 was significantly $(p<0.01)$ higher than that induced by $36 \mathrm{mM} \mathrm{K}$. CGRP concentration-dependently $(10 \mathrm{pM}-10 \mathrm{nM})$ reduced both the $\left[\mathrm{Ca}^{2+}\right]_{\mathrm{i}}$ and tension of coronary arteries precontracted with either U46619 or BAY K 8644, and also of resting coronary arteries in PSS. In $36 \mathrm{mM} \mathrm{K}{ }^{+}$-depolarized arteries, CGRP reduced only the tension without affecting the $\left[\mathrm{Ca}^{2+}\right]_{\mathrm{i}}$. In $300 \mathrm{nM}$ U46619 precontracted arteries, pretreatment with $10 \mu \mathrm{M}$ thapsigargin significantly $(p<0.05)$ attenuated the CGRP-induced reduction in the tension (but not $\left.\left[\mathrm{Ca}^{2+}\right]_{\mathrm{i}}\right)$. In $300 \mathrm{nM}$ U46619 precontracted arteries, pretreatment with either $100 \mathrm{nM}$ charybdotoxin or $100 \mathrm{nM}$ iberiotoxin or $10 \mathrm{nM}$ felodipine significantly $(p<0.05)$ attenuated the CGRP-induced reduction in both $\left[\mathrm{Ca}^{2+}\right]_{\mathrm{i}}$ and the tension. In contrast, $1 \mu \mathrm{M}$ glibenclamide did not affect the CGRP-induced responses in these coronary arteries. In resting coronary arteries, only pretreatment with the combination of $1 \mu \mathrm{M}$ glibenclamide and $100 \mathrm{nM}$ charybdotoxin attenuated the CGRP-induced decrease in the $\left[\mathrm{Ca}^{2+}\right]_{\mathrm{i}}$ and tension, suggesting a different mechanism of action for CGRP in resting coronary arteries. We conclude that CGRP relaxes precontracted rat coronary arteries via three mechanisms: (1) a decrease in $\left[\mathrm{Ca}^{2+}\right]_{\mathrm{i}}$ by inhibiting the $\mathrm{Ca}^{2+}$ influx through membrane hyperpolarization mediated partly by activation of $\mathrm{BK}_{\mathrm{Ca}}$ channels, (2) a decrease in $\left[\mathrm{Ca}^{2+}\right]_{\mathrm{i}}$ presumably by sequestrating cytosolic $\mathrm{Ca}^{2+}$ into thapsigargin-sensitive $\mathrm{Ca}^{2+}$ storage sites, and (3) a decrease in the $\mathrm{Ca}^{2+}$-sensitivity of the contractile apparatus. 

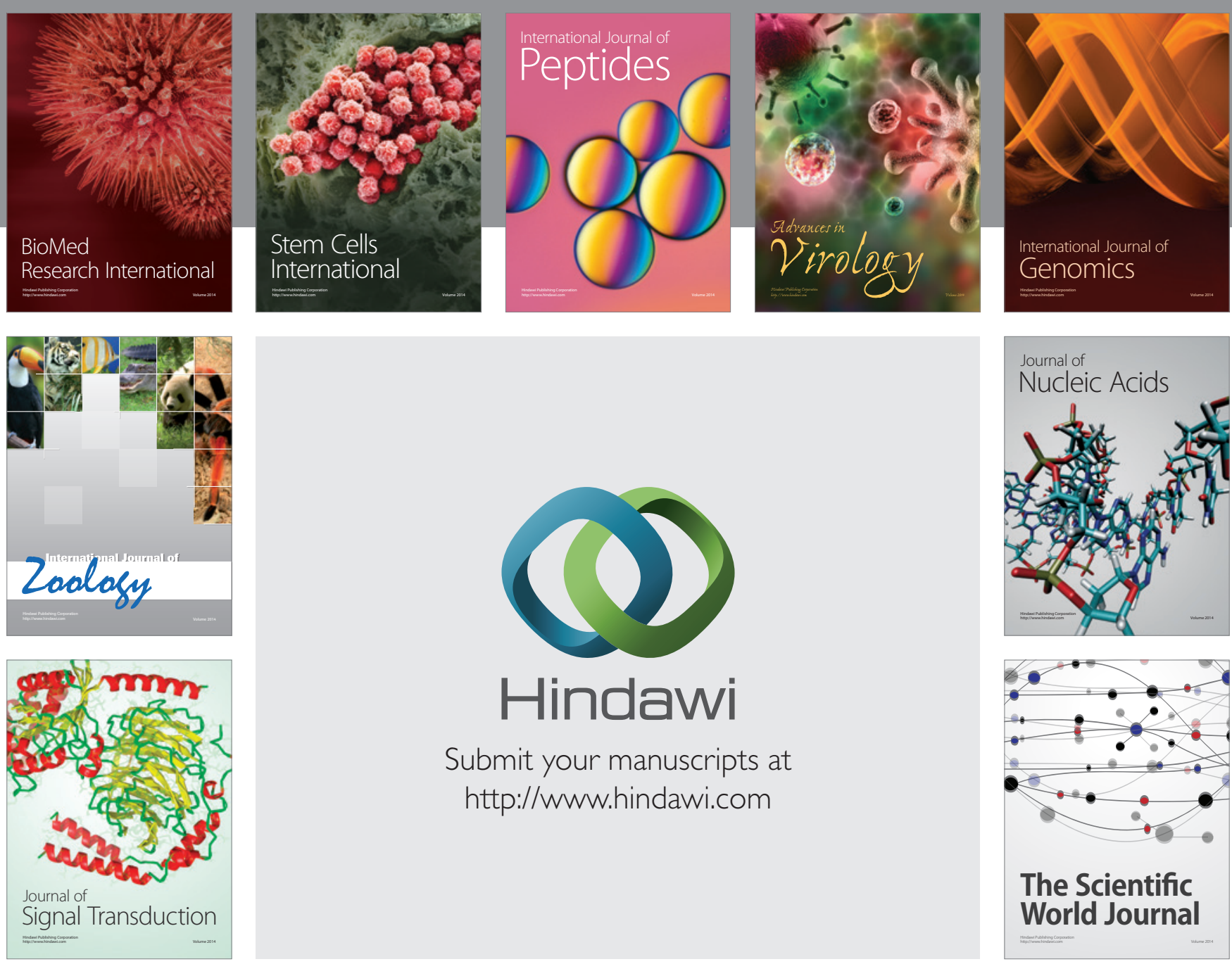

Submit your manuscripts at

http://www.hindawi.com
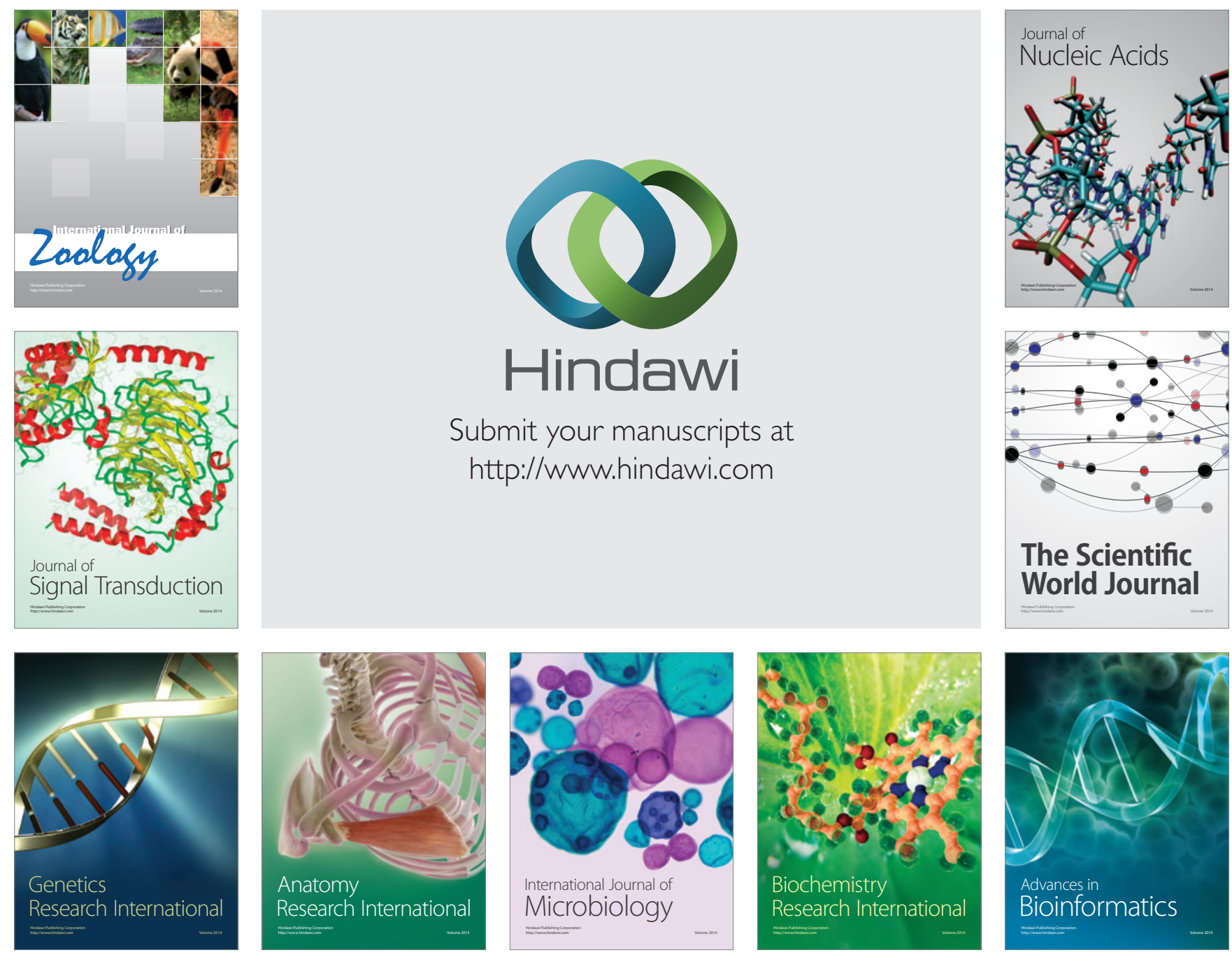

The Scientific World Journal
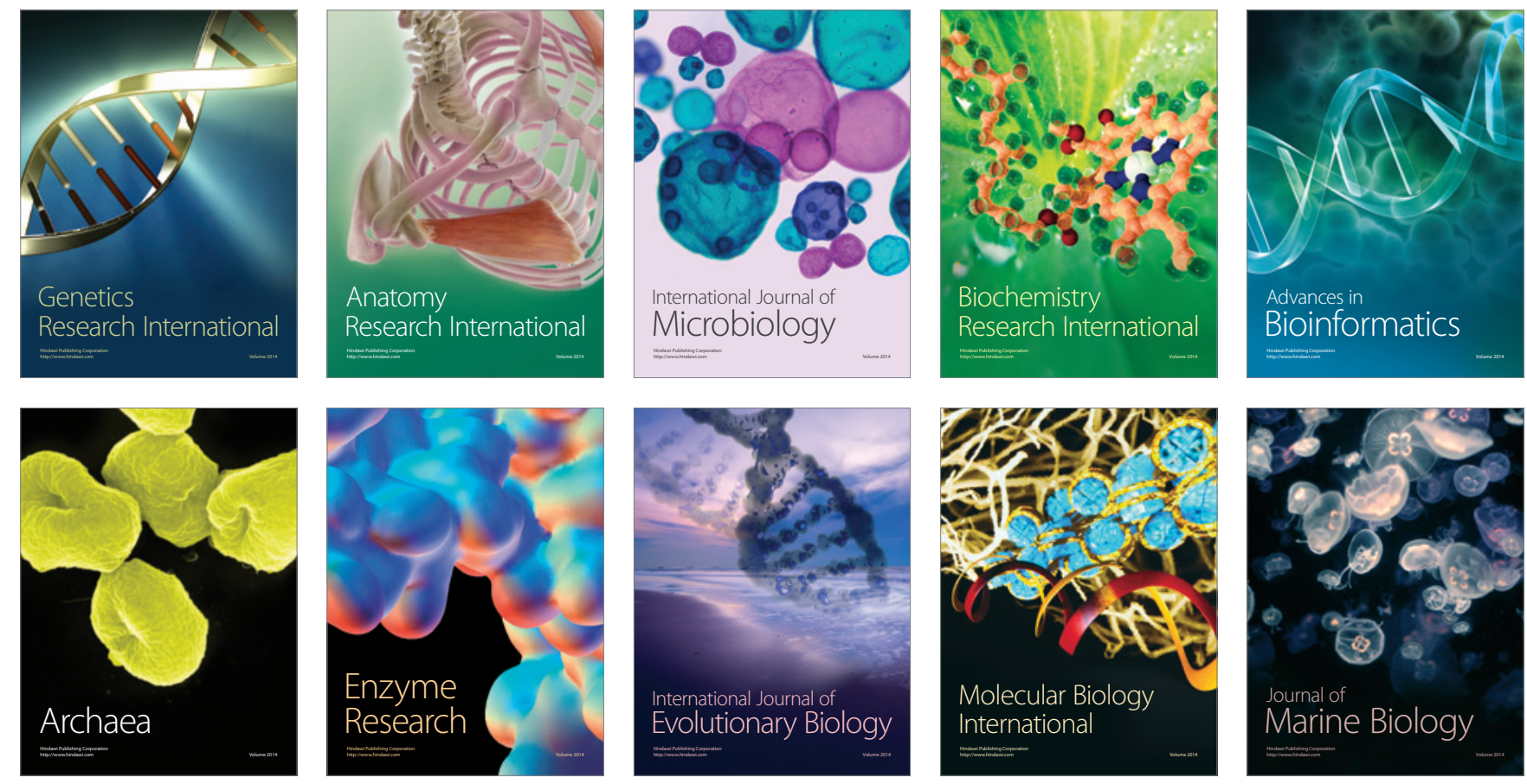